\title{
Challenges of 4D(ata) Model for Electronic Government
}

\author{
Bogdan GHILIC-MICU, Marian STOICA, Cristian USCATU \\ Bucharest University of Economics, Romania \\ ghilic@ase.ro,marians@ase.ro, cristiu@ase.ro
}

Social evolution pyramid, built on the foundation of the '90s capitalist society, lead to the emergence of the informational society - years 1990 to 2005 - and knowledge society - years 2005 to 2020. The literature starts using a new concept, a new form of association - artificial intelligence society - foreseen to be established in the next time frame. All these developments of human society and translations or leaps (most of the times apparently timeless) were, are and will be possible only due to the advancing information and communications technologies. The leap to Democracy 3.0, based on information and communication technologies prompts to a radical change in the majority of the classical concepts targeting society structure and the way it is guided and controlled. Thus, concepts become electronic concepts (or econcepts) through the use of new technologies. E-concepts keep the essence of the classical principles of liberty and democracy, adding a major aspect of the new way of communication and spreading ideas between people. The main problem is to quantify, analyze and foresee the way technological changes will influence not only the economic system, but also the daily life of the individual and the society. Unfortunately (or maybe fortunately, depending on the point of view), all these evolutions and technological and social developments are as many challenges for the governments of the world. In this paper we will highlight only four of the challenges facing the governments, grouped in a structured model with the following specific concepts: Big Data, Social Data, Linked Data and Mobile Data. This is an emerging paradigm of the information and communication technology supporting national and global eGovernment projects.

Keywords: Democracy 3.0, Big Data, Social Data, Linked Data, Mobile Data, eGovernment, Information and Communication Technology (ICT)

1

\section{Introduction}

An essential component of informational society is e-democracy, which concerns the activity and interactions of citizens, public institutions and political organizations through information and communications technology (ICT). The purpose of these activities is the development and promotion of democracy values through citizens' participation to the decisional process together with the public authorities, so that citizens can really see the results of their efforts. ICT facilities, especially communication environments used for interaction by citizens, organizations and public institutions become fundamental instruments in the process of modernization of society and government structures.

While electronic government mainly refers to accessibility of government services, electronic democracy refers to the citizen's active role in enlarging his possibilities through
ICT. Thus, electronic democracy allows citizens to get involved in public institutions' activity, taking part in the decisional process, and it allows the government to react adequately to citizens' needs [1].

Thus, in the last decade, the governments of the most developed economies have started a move towards e-government in order to improve services not only for citizens, but also for the business environment, promoting the social and economic development. Egovernment also means online interactions between government agencies, and government and employees, not only interactions between government and citizens. These interactions take place through online platforms, including mobile applications (mgovernment).

Information society impact on personal life and individual development of citizens may 
be analyzed from several points of view. Such an analysis must consider firstly the model of this new type of society with all its political, economic and social characteristics both on the level of individual countries and on international level.

This new concept implemented on country level helps users and has multiple benefic effects. Informational society relies heavily on large scale use of ICT at work, in relation with authorities and public institutions and everyday life (for shopping, instruction, and various other activities - Figure 1).

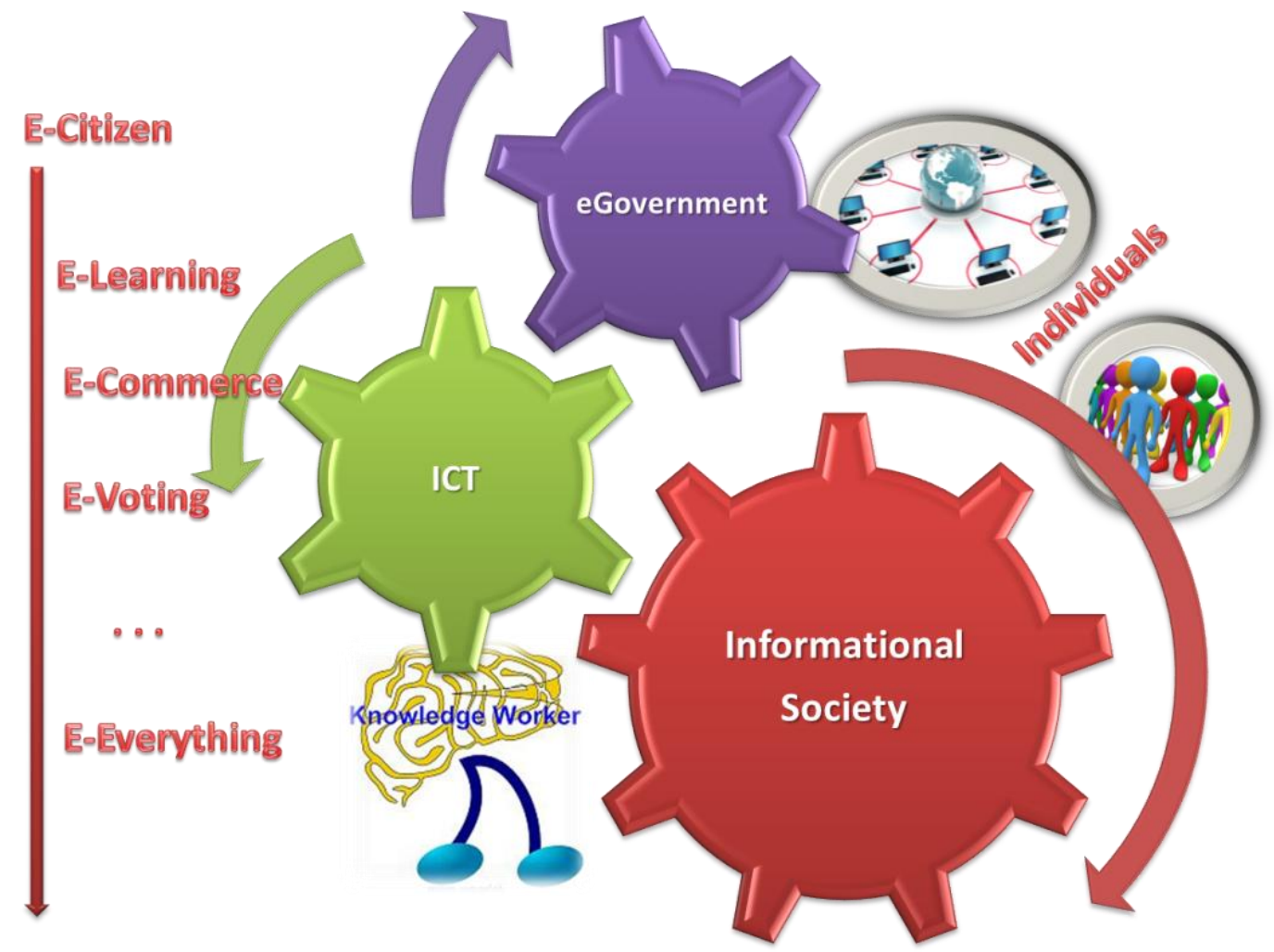

Fig. 1. Informational society and its relation with individuals

In the last years numerous analyses were carried out regarding public sector and its relations with society. Because of increased demand for public services, budget restrictions and high personnel costs, but also due to the help of new ICT features, the concept of electronic government or eGovernment was born and propagated.

\section{Electronic Government}

The literature provides many expressions and definitions related to electronic government concept. Still, there are some common elements that lead to a generally accepted definition. Thus, in a European approach, electronic government is defined as the use ICT in public administration, along with organizational changes and acquiring new competencies, in order to improve public services and democratic processes [2].

The concept itself refers, in principle, to the interactions between state public institutions and the citizens through electronic means. These interactions are not limited only to accessing information regarding current procedures or regulations. Electronic government also means more sensible elements like digital signature, electronic payment, electronic vote, laws and regulations, public procurement and electronic auctions, affidavits, licenses and approvals etc.

Governments are increasingly aware of the importance of changing the online services in order to make them available to as many citizens as possible (Table 1). However, the current approach is wrong and progresses slowly, leaving space for lots of improvements regarding the speed of accessing the infor- 
mation, its quality transparency, promoting to the proper users. The slow increase of eGovernment popularity compared to other online services lead the users to distrust online public services, creating a vicious circle.

Electronic democracy (e-government) manifestations go beyond the democratic process. No vision of informational society government would be complete without taking into account the digital democracy. The range of e-democracy covers, mainly, recording of poll participants, the poll act, consulting the public opinion, communication between elected persons and their constituents, encouraging people to take part into the legislative process etc. Live hearings, online expert consultation, public opinion consultation as well as open communication and information create opportunities for real time participation in the act of governing.

Table 1. eGovernment strategy benefits

\begin{tabular}{|c|c|c|}
\hline $\begin{array}{l}\text { Public sector } \\
\text { in relation } \\
\text { with }\end{array}$ & Examples & Benefits \\
\hline Citizens & $\begin{array}{ll}\checkmark & \text { Information } \\
\checkmark & \text { Culture } \\
\checkmark & \text { Health } \\
\checkmark & \text { Education } \\
\checkmark & \text { Transaction advantages } \\
\checkmark & \text { Tax collecting }\end{array}$ & $\begin{array}{l}\text { Wide range of means of communica- } \\
\text { tion, reduced costs for transactions, } \\
\text { expanded services, openness towards } \\
\text { democratic participation. }\end{array}$ \\
\hline Businesses & $\begin{array}{ll}\checkmark & \text { Support programs } \\
\checkmark & \text { Advice and help } \\
\checkmark & \text { Regulations } \\
\checkmark & \text { Tax collecting }\end{array}$ & $\begin{array}{l}\text { Fast, reduced transaction costs, facili- } \\
\text { tates transactions }\end{array}$ \\
\hline Suppliers & $\checkmark \quad$ E-procurement & $\begin{array}{l}\text { Reduced transaction costs, better stock } \\
\text { management, collaborative environ- } \\
\text { ments }\end{array}$ \\
\hline $\begin{array}{l}\text { Other compo- } \\
\text { nents of the } \\
\text { public sector }\end{array}$ & $\begin{array}{l}\text { Communication: } \\
\checkmark \quad \text { Between departments } \\
\text { and agencies } \\
\checkmark \quad \text { Between local and cen- } \\
\text { tral governments }\end{array}$ & $\begin{array}{l}\text { Increased efficiency, reduced transac- } \\
\text { tion costs, more efficient use of } \\
\text { knowledge bases, more flexible ar- } \\
\text { rangements }\end{array}$ \\
\hline
\end{tabular}

Electronic government is an instrument that contributes to the harmonization of relations between citizens and public authorities, based on mutual respect and interested collaboration between the state and citizens. Both theoreticians and practitioners identify and recognize (by use in specific projects) the four pylons of electronic government: G2C (government to citizen/consumer), G2B (government to business), G2G (government to government / administration), G2E (government to public employees). All these forms are based on electronic government principles, synthesized in six recommenda- tions (Figure 2):

A. Transparent partnership - all activities must be transparent, publicly discussed, considering the opinions and ideas of all parties involved;

B. Accessible information - respect the citizens fundamental right of access to public information;

C. Social orientation - implement electronic government considering the citizens' needs;

D. Legislative harmonization - harmonize the legal framework with international regulations and standards; 
E. Protection and security - respect the constitutional rights and liberties of citizens in the process of creating, storing, processing and transmitting information, including protection of personal data, through means and methods of ensuring information security;

F. Priority for political, economic and social dimension against the technological aspects.

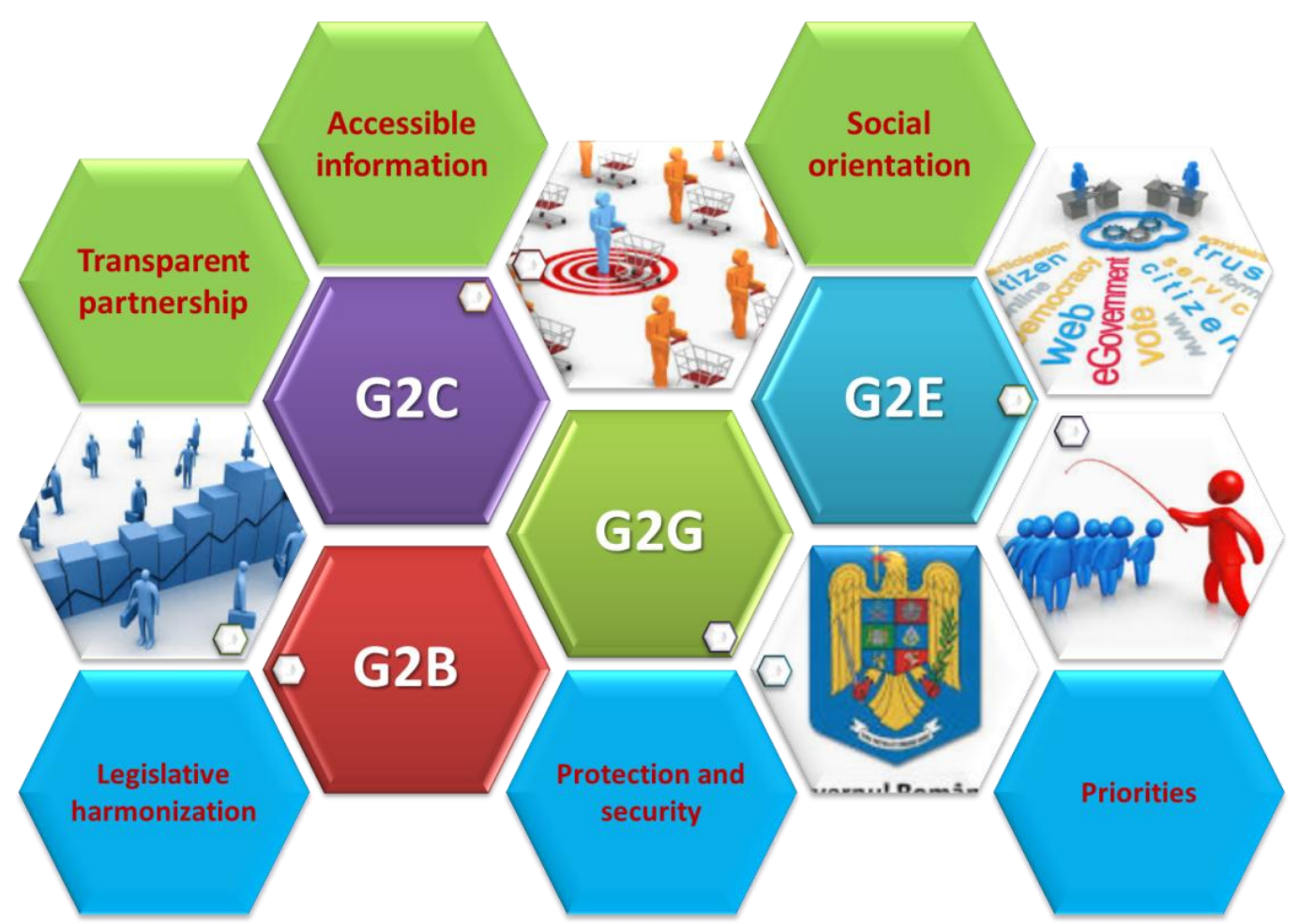

Fig. 2. Principles of electronic government

Electronic government provides administrations with an online environment for providing information, observing the most important concepts of electronic environment [3]. Also, the 4D(ata) approach highlights the benefits of applying Linked Data and Big Data concepts. The accent is on accountability of governments regarding public data. Also, Social Data concept evaluates the social dimension of electronic government.

\section{Big Data Dimension of 4D(ata) Model}

A multitude of references in literature puts Big Data either in the category of abstract concepts or specific instruments of information and communications technology. For comprehensiveness, our approach will consider both aspects. Thus, we may define Big Data as the concept used to describe datasets of such large size and high complexity that prevents standard applications to process them. The size of these datasets is above the possibilities of typical database systems (SGBD) to collect, process, manage and analyze. Because they may come from a wide range of domains (social, political, economic, scientific, cultural etc.) they are important for competition, increasing productivity, innovation and increasing the number of consumers. The premises of Big Data development are found, firstly, in the spectacular development of ICT in the last years, which allows today's world to be better connected, easier to find / locate, hear / listen. From the perspective if ICT instruments, Big Data may be defined as the technology that processes large volumes of data, beyond the usual abilities of traditional data bases. Thus, the Big Data has the two facets of a coin: the descriptive part in the concept (objective facet) and the applicative part in the technology (subjective facet). Although one of sectors that benefit most from Big Data is the business sector, public sector is not outside its influence [4]. On the 
contrary, Big Data may help lots of governments in serving their citizens, overcoming the national problems and challenges like unemployment and fraud fight (for example the American program Medical Fraud Strike Force - http://www.stopmedicarefraud.gov).

On European side, the first government to employ Big Data was Great Britain, through Horizon Scanning Center. Using this project, the British government tried to find answers to the problem of global warming, regional and international tensions and security. The project with the most significant impact on electronic government was launched in 2009 through the public portal www.data.gov.uk. It provides users, since the first year of launch, with thousands of datasets to help them understand the governing ways and policies. The platform offers the citizens the possibility to get involved in electronic government, giving them the e-citizen statute [5].

\section{Social Data Dimension of the 4D(ata) Model}

There are multiple possibilities to define Social Media. Most definitions highlight three important elements: (1) user generated content, (2) communities and (3) Web 2.0. [6] Globalwebindex, for example, quoted by [7], provides the statistics regarding the use of Social Media (http://www.globalwebindex.net). First four platforms on top are Facebook, Google+, Youtube and Twitter. The next three platforms are social networks from China, including Sina Weibo, Tencent, Weibo and Qzone.

In the context of the proposed $4 \mathrm{D}$ (ata) paradigm, Social Data means the structured information obtained from analyses and statistics that describes the behavior patterns of individuals regarding certain public interest subjects. The information is drawn from the use of electronic platforms, mainly social platforms and web services that favor human interaction. This information is gathered on a specific time frame and used to extrapolate certain behavior patterns or collective trends of change (in specific domains of interests: culture, sport, education, entertainment, fashion etc.).

The perspective of electronic government must perceive Social Data in terms of data voluntarily created and disseminated by citizens through social platforms. This type of data is mainly subjective and they must be considered appropriately in e-government strategies (Table 2).

Table 2. Stages and phases of e-government strategy

\begin{tabular}{|c|c|c|}
\hline Stages & Phases & Observations \\
\hline \multirow{3}{*}{ Informative } & Incipient & $\begin{array}{l}\text { In this phase the government has a limited online } \\
\text { presence, consisting of simple web pages, usually } \\
\text { prompted by social initiatives. }\end{array}$ \\
\hline & Development & $\begin{array}{l}\text { More web pages and complex applications are em- } \\
\text { ployed. The sector takes a more important segment }\end{array}$ \\
\hline & Expansion & $\begin{array}{l}\text { Web pages use technologies that interrogate data- } \\
\text { bases in governmental intranet, there are no major } \\
\text { changes, but the volume of information is increased. }\end{array}$ \\
\hline \multirow{3}{*}{ Interactive } & Incipient & $\begin{array}{l}\text { E-mails and complaints are receives. Search en- } \\
\text { gines, forums and chats are implemented. }\end{array}$ \\
\hline & Operational & $\begin{array}{l}\text { Users have easier and more efficient access to in- } \\
\text { formation through new informatics solutions im- } \\
\text { plemented. }\end{array}$ \\
\hline & $\begin{array}{l}\text { Pre- } \\
\text { transactional }\end{array}$ & $\begin{array}{l}\text { Secured pages and passwords are implemented, } \\
\text { online orders can be placed, there is a move towards } \\
\text { electronic market. There are online forms every- }\end{array}$ \\
\hline
\end{tabular}




\begin{tabular}{|c|c|c|}
\hline Stages & Phases & Observations \\
\hline & & where. \\
\hline \multirow{3}{*}{ Transactional } & Pilot & $\begin{array}{l}\text { Authentication methods are tested. Gradually move } \\
\text { towards providing government services on internet. }\end{array}$ \\
\hline & Intermediary & $\begin{array}{l}\text { Population starts to use transactional characteristics } \\
\text { of web sites, but in small numbers. This is the first } \\
\text { measurable reaction of citizens. }\end{array}$ \\
\hline & Full use & $\begin{array}{l}\text { Electronic services and new communication chan- } \\
\text { nels are accessed by large numbers of citizens. Peo- } \\
\text { ple now know how to efficiently use e-government. }\end{array}$ \\
\hline Integrative & Implementation & $\begin{array}{l}\text { There is a large similarity in the ways services are } \\
\text { provided on the web (user friendly interfaces, secure } \\
\text { links), hence portals appear. }\end{array}$ \\
\hline
\end{tabular}

Social Data dimension is used by the government to understand the public opinion, anticipate the reaction to adoption of governmental decision.

\section{Linked Data Dimension of 4D(ata) Model}

The term of Linked Data (interconnected data) was introduced by Sir Tim Berners-Lee, director of World Wide Web (W3C) consortium and creator of World Wide Web (in 1990), in one of his works on the architecture of web space [1], [8]. The term describes a way of publishing and interconnecting data in a structured form, starting from the idea that data becomes more valuable and more credible when they are connected to other data. This model seeks to standardize data from heterogeneous sources, using as main rules the RDF model (Resource Description Framework) in order to publish structured data on the web.

As dimension of $4 \mathrm{D}$ (ata) paradigm in relation with electronic government, Linked Data describes a way to publish structured data so that they interconnect and increase their usability through semantic queries. This data may be built on current standards, like HTTP, RDS or URI (Uniform Resource Identifier), with the goal of enriching computing units data bases, leading to more rele- vant results.

There are numerous benefits for governments using linked data standards to publish data. Lots of governments have started a decade ago to create a governmental linked data web space inside an interconnected data cloud. These attempts involve a more responsible and secure availability of data and for consumers this translates into easier and more flexible access to government data.

In the last years there are more and more government projects involving the use of Linked Data. Starting with www.data.gov platform of United States (figure 3) and continuing with European Union LATC (Linked open data Arround The Clock), PlanetData project, DaPaaS (Data and Platform as a Service) project and Linked pen Data 2 (LOD2) project, they all provide thousands of datasets for every user.

Linked Data standards provide numerous opportunities for government actions regarding statistics and geo-spatial information because the most useful datasets also contain statistical information, whether it is the number of vehicles registered in a year or the real location of a certain event. Both domains have the same large numbers of interested users, thus the use of Linked Data standard is benefic. 


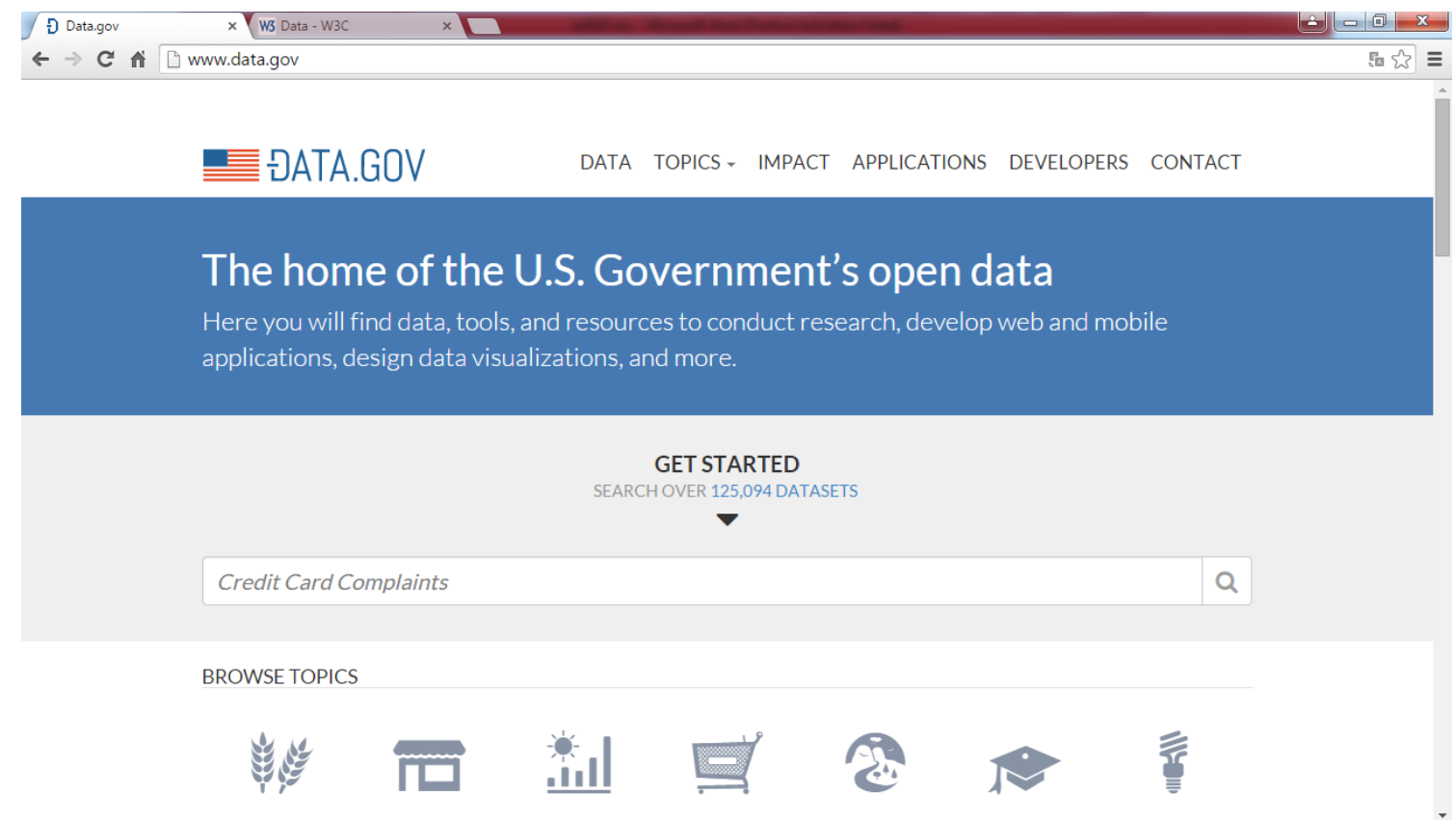

Fig. 3. Open Data portal of United States government

One example of Linked Data for geo-spatial information is provided by the British government. Through the INSPIRE directive, Great Britain makes sure the European countries exchange spatial information. Among other functionalities, the directive provides identifiers for spatial objects and a resolution mechanism (built on standard web architecture).
The equivalent of this British initiative in Romania is http://data.gov.ro (still in beta version for now - see Figure 4), that follows a similar model. Through the 2013-2016 Government Program, with the support of Department of design and Online Service, citizens are empowered to "identify, download and use data sets the are public or owned by public administration" [4].

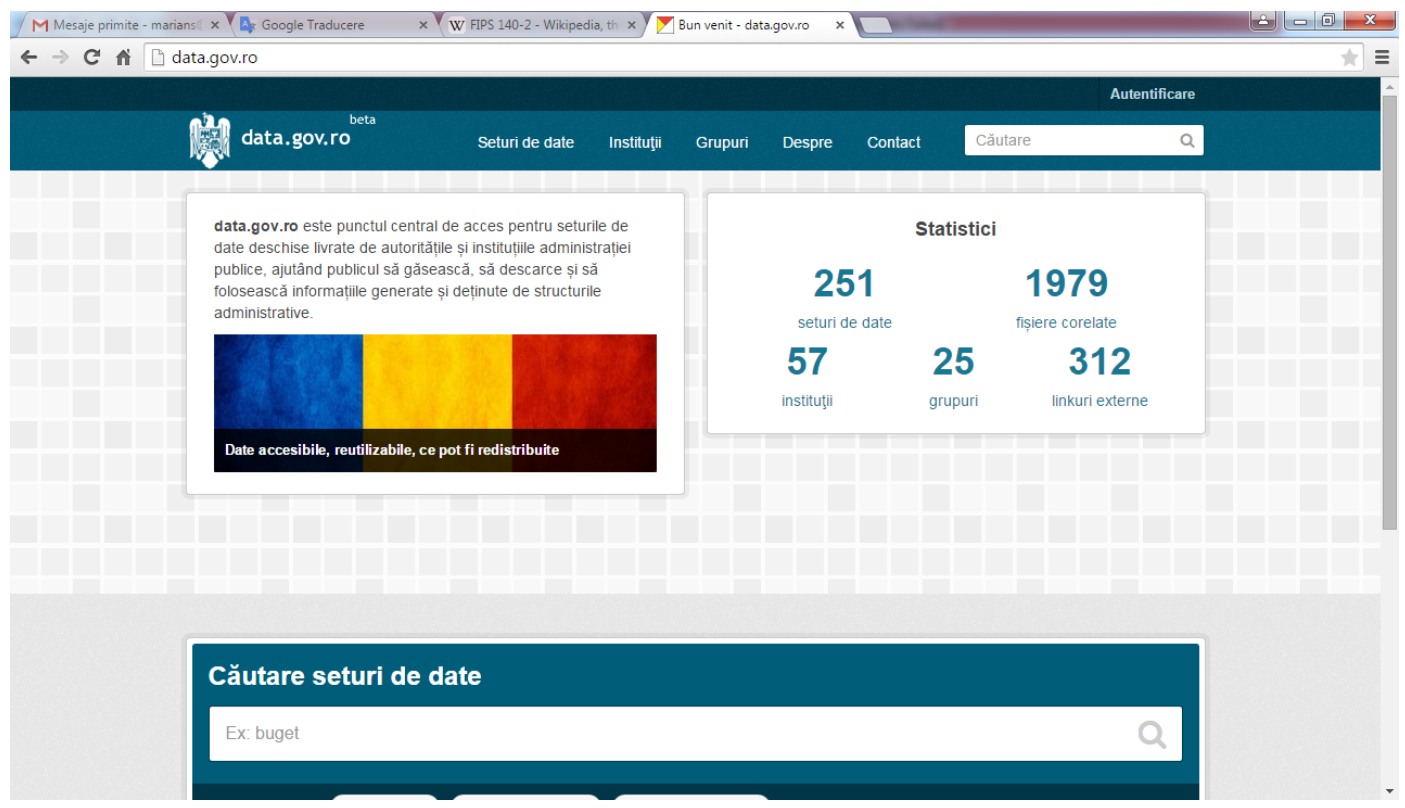

Fig. 4. Open Data portal of Romania government

The Romanian portal provides citizens with 251 data sets from various sources: Ministry of Public Finances (59), Ministry of Justice (19), Ministry of Health (18) etc. General 
Anticorruption Department (DGA) also provides nine reports, some of them targeting the evaluation and implementation of some laws, "Centralized report on DGA personnel travels in 2013", and other general interest information. Not all institutions provide information, not all information is complete and up to date, but data.gov.ro promises to facilitate access to all public government data, in an unified manner.

\section{Mobile Data Dimension of 4D(ata) Model}

Like the other three dimensions of the 4D(ata) paradigm related to electronic government, Mobile Data is a natural consequence of technological development. The mobile phone has evolved from a simple voice device to multimedia communications, able to access and transfer audio and video data, functioning also as a global positioning device, electronic wallet etc. In this context, government applications may take advantage of the functionalities of this widely used device.

Correlated with the terms previously analyzed, Mobile Data means the possibility to provide citizens with a collection of instruments for strategic use of governmental services or applications available only for mobile devices, laptops, tablets and wireless internet infrastructure.

The relation between citizens and the government has changed since the apparition of Open Data concept and mobile applications. They now interact through application for public transportation payment through mobile phone, emergency applications etc. on the background of a trend to provide more transparent public data. In a continuously changing society, adapting to more flexible economic and political conditions, the changes do not stop here (see the concept of democracy 3.0).

For example, in USA, government agencies have developed applications for airport security (MyTSA - Transportation Security Administration) or applications that help small enterprises to apply for various regulations. Other applications provide instructions for emergency situations, maps to shelters and rescue centers. Still, the potential of mobile data is only exploited by governments on a small scale.

The possibilities are vast, for example: $\mathrm{Na}-$ tional Agency for Environment Protection might develop applications for monitoring fires and natural disasters. In order to help the development of this area, the government must collaborate with the business and academic environments, for mobile and web applications to provide through clouds general interest data, open and available to solve real problems. Due to the increased number of mobile devices in use (each with internet connection, GPS features, development applications), governments must look into the security of mobile data. In USA, for example, security requirements for the mobile environment are established in the FIPS 140-2 standard (the Federal Information Processing Standard), that certifies cryptographic modules, protecting inactive data (data at rest) and active data (data in use) for public sector (four levels of security).

In this context, the move to mGovernment is still a challenge for governments, which must choose from multiple possibilities and technical solutions. Although required resources are available, after planning, development and testing there is the problem of launching, acceptance from citizens, maintenance and security.

\section{Conclusions}

Electronic government must be a goal by itself. Unfortunately, in Romania all the ideas and efforts of the government have been so far only answers to requests from outside and were oriented on technology, neglecting all social, political and economic aspects. A more complex approach, better coordinated and closer to Romanian realities may have better results and lower costs. A few failures in implementation of western policies in other domains should have taught us already that in Romania it is hard to build on large scale due to political cycle, budget restrictions and mentalities. Although, we must not overlook projects that enjoy continued success (for ex- 
ample the governmental portal for public procurement SEAP - www.e-licitatie.ro).

The concepts of Big Data, Social Data, or Mobile Data may be successfully integrated in order to increase the efficiency of activities in multiple governmental segments. This can lead to significant benefits for the state, like increased trust, and for the citizens, by improving the interactions with government institutions.

While the implementation of electronic government was an important decision, adopted by most governments of the world, mobile technologies had a fast advancement and development, making the use of mobile technologies for providing services and information a requirement rather than an option. Since there is a continued demand for mobility and public sector efficiency and productivity increases by using mobile technologies, we foresee a move from eGovernment to mGovernment. Thus, mobile government is the next step in the process of using information and communications technology for public sector.

\section{Acknowledgement}

A shorter version of this paper was presented at the 14th International Conference on Informatics in Economy (IE 2015), May 1-3, 2015.

\section{References}

[1] W3C.

Internet:

http://www.w3.org/standards/semanticwe b/data, 2013, [Feb. 20, 2015].

[2] Roșca I. Gh., Ghilic-Micu B., Stoica M. - coord., Informatica. Societatea Informațională. E-Serviciile,Economica Publishing House, 2006.

[3] Programul de guvernare 2013-2016. Internet: http://data.gov.ro/about, [Feb. 20, 2015].

[4] European eGovernment Action Plan 2011-2015. Internet:

http://ec.europa.eu/digitalagenda/en/european-egovernment-actionplan-2011-2015, Digital agenda for Europe, A Europa 2020 Initiative, [Feb. 20, 2015].

[5] Internet: http://data.gov.uk/faq, [Feb. 20, 2015].

[6] T. Ahlqvist, A. Bäck, M. Halonen and S. Heinonen (2008), Social Media Roadmaps. Exploring the futures triggered by social media, [On-line]. VTT Technical Research Centre of Finland, ESPOO 2008, VTT TIEDOTTEITA research notes 2454 ISBN 978-951-387247-2, Available: http://www.vtt.fi/publications/index.jsp [Feb. 20, 2015].

[7] M. Hu and L. Bing, "Mining and Summarizing Customer Reviews", in Proceedings of ACM Conference on Knowledge Discovery and Data Mining (ACMSIGKDD-2004), Seattle, Washington, 2004.

[8] Epimorphics Ltd. Internet: http://www.epimorphics.com/web/resourc es/what-is-linked-data, 2012, [Feb. 20, 2015].

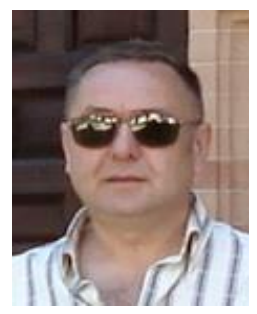

Bogdan GHILIC-MICU received his degree on Informatics in Economy from the Bucharest University of Economic Studies in 1984 and his doctoral degree in economics in 1996. Between 1984 and 1990 he worked in Computer Technology Institute from Bucharest as a researcher. Since 1990 he teaches in Bucharest University of Economic Studies, at Informatics and Cybernetics Economy Department. His research activity, started in 1984 includes many themes, like computers programming, software integration and hardware testing. The main domain of his last research activity is the new economy - digital economy in information and knowledge society. Since 1998 he managed over 25 research projects like System methodology of distance learning and permanent education, The change and modernize of the economy and society in Romania, E-Romania - an information society for all, Social and environmental impact of new forms of work and activities in information society. 


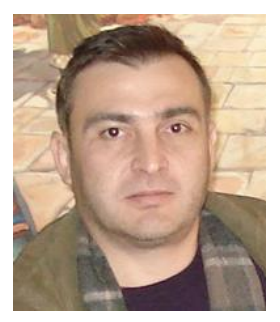

Marian STOICA received his degree on Informatics in Economy from the Bucharest University of Economic Studies in 1997 and his doctoral degree in economics in 2002. Since 1998 he is teaching in Bucharest University of Economic Studies, at Informatics and Cybernetics Economy Department. His research activity, started in 1996 and includes many themes, focused on management information systems, computer programming and information society. The main domains of research activity are Information Society, EActivities, Tele-Working, and Computer Science. The finality of research activity still today is represented by over 80 articles published, 25 books and over 40 scientific papers presented at national and international conferences. Since 1998, he is member of the research teams in over 30 research contracts with Romanian National Education Ministry and project manager in 5 national research projects.

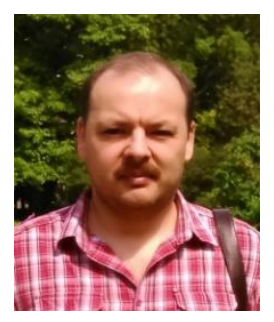

Cristian Răzvan USCATU received his degree on Informatics in Economy from the Academy of Economic Studies, Bucharest in 1997 and his doctoral degree in economics in 2007. In the present he is Associated Professor, $\mathrm{PhD}$, currently working with the Bucharest University of Economic Studies, Faculty of Cybernetics, Statistics and Informatics, Department of Informatics and Cybernetics in Economy. Competence areas: computer programming, data structures. Author/co-author of more than 10 books and 40 papers published in national and international journals. 